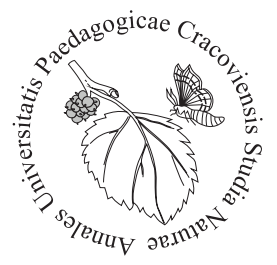

Renata Muchacka1*, Ewa Sosnówka-Czajka², Iwona Skomorucha², Edyta Kapusta' ${ }^{1}$, Agnieszka Greń1, Zofia Goc

${ }^{1}$ Department of Animal Physiology and Toxicology, Institute of Biology, Pedagogical University of Cracow, Podbrzezie 3, 30-054 Kraków, Poland, ${ }^{\star}$ renata.muchacka@up.krakow.pl ${ }^{2}$ Department of Poultry Breeding, National Research Institute of Animal Production, Krakowska 1, 32-083 Balice n. Kraków, Poland

\title{
Antioxidant enzymes activity, GSH and MDA level in eggs from heritage breeds
}

Introduction

In eggs, as in any raw food material, there are a number of different quality changes. The moment of laying the egg is a specific beginning of these changes. From that moment, the eggs begin to undergo metabolic processes that contribute to the gradual deterioration of the quality of the raw material until the loss of consumer and technological usefulness (Jankowska, 2010). On the farm, there is a group of factors that have an impact after the egg is laid and modifies their quality. These include hygienic conditions, and the manner and conditions for the collection and distribution of raw egg product. The temperature and distribution time between the producer and the consumer as well as the storage conditions are decisive here (Calik, 2011). Another group are factors that affect the quality of eggs even before they are laid depend on the laying hens and, to a large extent, on the farmer. The quality of eggs is influenced by the origin of laying hens (i.e. breed, line). It affects, among other things, the size of the egg, the colour of the eggshell, and the nutritional value (Singh et al., 2009; Calik, 2013). Moreover, the following factors are also important: the age of the laying hens (older hens laid larger eggs, but of inferior quality shells), the rearing system, their feeding (Batkowska, Brodacki, 2017), and veterinary prevention (Calik, 2013).

The aim of the study was to determine the differences in antioxidant enzyme activities and differences in the level of reduced glutathione and malondialdehyde in eggs from three heritage breeds. 
Hens and experimental design

The experiment was carried out with 99 hens, approximately 48 weeks of age, of three heritage breeds, 'Greenleg Partridge' (Z-11), 'Sussex' (S-66), and 'Rhode Island Red' (R-11), which were assigned to Groups I to III (33 hens per group), respectively. Each group was subdivided into 3 subgroups, each having 11 birds. Hens were reared in the litter system at a stocking density of 9 birds $\cdot \mathrm{m}^{-2}$ and had outdoor access with green paddocks $\left(2.5 \mathrm{~m}^{2} / \mathrm{hen}\right)$. The birds were fed ad libitum with standard diets based on concentrates for laying hens, which contained $17.5 \%$ protein and 11.6 MJ ME/ $\mathrm{kg}$ feed (Fig. 1). The diet consisted of wheat, maize, soybean expeller, dried alfalfa, rapeseed oil, limestone, di-calcium phosphate, common salt, DL-methionine, and DJ prefix. The birds had free access to water throughout the experiment. All the groups were managed under uniform environmental (air humidity and temperature, lighting programme) and feeding conditions. A lighting schedule of $16 \mathrm{~h}$ of light and $8 \mathrm{~h}$ of darkness (16L : 8D) was used.

\section{Sample collection and laboratory analyses}

At 48 weeks of age, 6 eggs from each group were collected for the next three days. Eggs were evaluated after $24 \mathrm{~h}$ of refrigerated storage at $4^{\circ} \mathrm{C}$ and $55 \%$ humidity. In the samples of egg yolks and albumens, the concentration of glutathione (GSH) and malondialdehyde (MDA), and the activity of superoxide dismutase (SOD), glutathione peroxidase (GPx), and catalase (CAT) were estimated. The collected yolks and albumens were homogenised in $50 \mathrm{mM}$ phosphate buffer cooled to $4^{\circ} \mathrm{C}$ and containing $\mathrm{K}_{2} \mathrm{HPO}_{4}$ (dipotassium hydrogen phosphate) $+\mathrm{KH}_{2} \mathrm{PO}_{4}$ (potassium dihydrogen phosphate) +

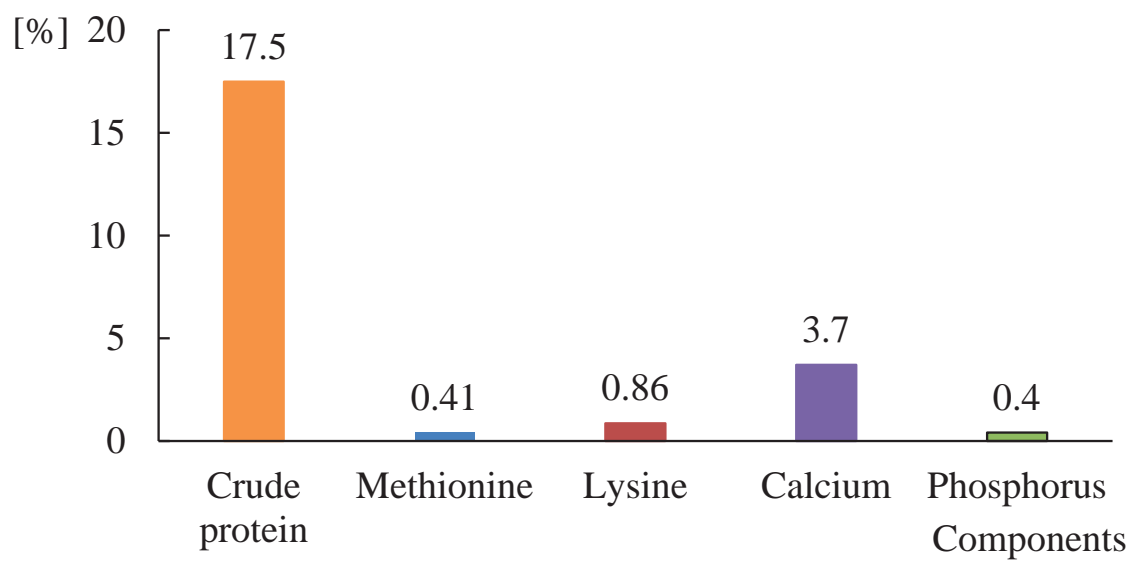

Fig. 1. Nutritive value of the diet 
$0.1 \mathrm{mM}$ EDTA (ethylenediaminetetraacetic acid disodium salt) $(\mathrm{pH}=7.0)+0.1 \%$ BSA (bovine serum albumin) and then centrifuged. The obtained supernatants of the yolks and albumens were used for further investigations.

The activity of SOD in the supernatants of homogenates of yolks and albumens was determined according to spectrophotometric cytochrome method by Diplock et al. (1991). The activity of CAT was determined according to the spectrophotometric method by Aebi (1983), and the activity of GPx was estimated by the modified method of Lück (1963). The activity of the studied antioxidative enzymes in yolk and albumen extracts was expressed in $\mathrm{U} \cdot \mathrm{mg}^{-1}$ of protein.

MDA reacts with thiobarbituric acid (TBA) in an acid medium and the produced coloured TBA-complex that could be measured colorimetrically according to the method of Ohkawa et al. (1979). MDA concentration was expressed in $\mathrm{nM} \cdot \mathrm{mg}^{-1}$ protein. Total protein concentration in the supernatants of homogenates of the yolk and albumen was determined according to the Bradford method (1976) with bovine serum albumin as a standard.

In the supernatants of yolks and albumens, obtained after deproteinisation and centrifugation, GSH was determined according to the method of Ellman (1959). The concentration of GSH was estimated in the yolk and albumen in $\mu \mathrm{M} \cdot \mathrm{g}^{-1}$ of protein.

Statistical analysis

All data was analysed by the analysis of variance procedures (ANOVA) and Duncan's multiple-range test using the computer program Statistica version 10.0 PL. The data was expressed as means \pm SD and was considered as significant when $\mathrm{P}$ values were less than 0.05 .

Tab. 1. Antioxidant enzymes activity and the level of MDA and GSH in yolk; values shown as different letters within the line differ significantly according to the Duncan test at $\mathrm{p} \leq 0.01$

\begin{tabular}{ccccc}
\hline Item & \multicolumn{3}{c}{ Group } & SD \\
& I & II & III & 1.0810 \\
SOD $[\mathrm{U} / \mathrm{mg}]$ & $3.0240 \mathrm{a}$ & $7.5730 \mathrm{~b}$ & $3.0130 \mathrm{a}$ & 0.0034 \\
$\mathrm{GPx}[\mathrm{U} / \mathrm{mg}]$ & 0.0044 & 0.0065 & 0.0048 & 0.0620 \\
$\mathrm{CAT}[\mathrm{U} / \mathrm{mg}]$ & 0.0470 & 0.0650 & 0.0890 & 0.0170 \\
$\mathrm{GSH}[\mu \mathrm{M} / \mathrm{g}]$ & $0.3410 \mathrm{~b}$ & $0.3850 \mathrm{~b}$ & $0.1250 \mathrm{a}$ & 0.0460 \\
$\mathrm{MDA}[\mu \mathrm{g} / \mathrm{g}]$ & $2.4490 \mathrm{ab}$ & $2.2500 \mathrm{a}$ & $2.4680 \mathrm{~b}$ & \\
\hline
\end{tabular}

Results

The highest activity of SOD, both in yolks (Tab. 1) and albumens (Tab. 2), was found in eggs of Sussex hens ( $\mathrm{p} \leq 0.01)$. GPx and CAT activity was in all eggs at a similar level. The highest level of GSH was in egg yolks of 'Greenleg Partridge' and 'Sussex' hens ( $\mathrm{p} \leq 0.01)$ 
(Tab. 1) and in egg albumens of 'Greenleg Partridge' hens ( $\mathrm{p} \leq 0.01)$ (Tab. 2). The lowest level of MDA was found in egg yolk and egg albumen of 'Sussex' hens ( $\mathrm{p} \leq 0.05)($ Tab. 1-2).

Tab. 2. Antioxidant enzymes activity and the level of MDA and GSH in albumen; values shown as different letters within the line differ significantly according to the Duncan test at $\mathrm{p} \leq 0.01$

\begin{tabular}{|c|c|c|c|c|}
\hline \multirow{2}{*}{ Item } & \multicolumn{3}{|c|}{ Group } & \multirow{2}{*}{ SD } \\
\hline & I & II & III & \\
\hline $\mathrm{SOD}[\mathrm{U} / \mathrm{mg}]$ & $1.1320 \mathrm{a}$ & $3.1870 \mathrm{~b}$ & $1.1290 \mathrm{a}$ & 0.4580 \\
\hline $\mathrm{GPx}[\mathrm{U} / \mathrm{mg}]$ & 0.0049 & 0.0062 & 0.0079 & 0.0032 \\
\hline $\mathrm{CAT}[\mathrm{U} / \mathrm{mg}]$ & 0.0640 & 0.0650 & 0.0940 & 0.0660 \\
\hline $\mathrm{GSH}[\mu \mathrm{M} / \mathrm{g}]$ & $0.3250 \mathrm{~b}$ & $0.1500 \mathrm{a}$ & $0.1460 \mathrm{a}$ & 0.0160 \\
\hline $\mathrm{mDA}[\mu \mathrm{g} / \mathrm{g}]$ & $1.8790 \mathrm{ab}$ & $1.6080 \mathrm{a}$ & $1.9130 \mathrm{~b}$ & 0.0220 \\
\hline
\end{tabular}

Discussion

In optimal conditions, there is a balance between oxidants and antioxidants in the body. The increase in free radical production or decrease of antioxidant activity causes a disturbance of balance in the oxidation reaction, which is called oxidative stress. During oxidative stress, stationary concentrations of reactive oxygen species (ROS) increase significantly. Free radicals oxidize row fatty acids (lipids), structural proteins, and enzymatic proteins (Surai, 2015). Therefore, it is important that the body's antioxidant system functions properly. The quality characteristics of eggs and also the antioxidant enzymes and GSH found in the eggs are synthesised and formed in the hen's body during eggs formation. According to our research, the activity of antioxidant enzymes (mainly SOD) and the levels of GSH and MDA found in eggs differ depending on the breed of hens. The highest activity of SOD, the highest level of GSH, and the lowest level of MDA were characterised by eggs from Sussex hens, which may indicate they have the best quality. Similar results were obtained in the previous studies by Muchacka et al. (2016; 2018). It is known that the origin of the laying hens (i.e. breed, line) affects the quality of eggs. It affects egg size, shell colour, and the nutritional value (Singh et al., 2009; Calik, 2013) and probably the activity of antioxidant enzymes and levels of GSH (Muchacka et al., 2016; 2018). Differences in the activity of antioxidant enzymes and GSH levels may be caused by differences in the metabolism of the tested hens. It may be important because these substances can affect the quality of the poultry products, e.g., eggs and protect the germ cell and growing embryo against ROS in the first days after the egg is laid.

Based on the obtained results, it can be concluded that the activity of antioxidant enzymes (mainly SOD) and the levels of GSH and MDA which occur in eggs may depend on the breed of hens and may indicate their quality; however, further studies on this topic are necessary. 


\section{References}

Aebi, H.E. (1983). Catalase. In: H.U. Bergmeyer (ed.), Methods of Enzymatic Analysis. New York: Academic Press, pp. 273-286.

Batkowska, J., Brodacki, A. (2017). Selected quality traits of eggs and the productivity of newly-created laying hens dedicated to extensive system of rearing. Archives of Animal Breeding, 60, 87-93.

Bradford, M.M. (1976). A rapid and sensitive method for the quantitation of microgram quantities of protein utilizing the principle for protein-dye binding. Analytical Biochemistry, 72, 248-254.

Calik, J. (2011). Ocena jakości jaj sześciu rodów kur nieśnych w zależności od ich wieku. Żywność Nauka Technologia Jakość, 5(78), 85-93. [In Polish]

Calik, J. (2013). Zmiany cech jakościowych jaj pochodzących od kur nieśnych Żółtonóżka Kuropatwiana (Ż-33), w zależności od warunków ich przechowywania. Żywność Nauka Technologia Jakość, 2(87), 73-79. [In Polish]

Diplock, A.T., Symons, M.C.R., Rice-Evans, C.A. (1991). Techniques in free radical research. London: Elsevier.

Ellman, G.L. (1959). Tissue sulfhydryl groups. Archives of Biochemistry and Biophysics, 82, 70-77. DOI: 10.1016/0003-9861(59)90090-6

Jankowska, K. (2010). Od zniesienia do konsumpcji - jaja kurze (spożywcze). Zachowanie higieny w produkcji jaj. Polskie Drobiarstwo, 2, 52-54. [In Polish]

Lück, H. (1963). Peroxidases. In: H.U. Bergmeyer (ed.), Methods of enzymatic analysis. New York: Academic Press, pp. 895-897.

Muchacka, R., Sosnówka-Czajka, E., Skomorucha, I. (2018). Antioxidant enzymes activity, GSH and MDA level in eggs from heritage breeds reared under organic conditions. $8^{\text {th }}$ International Scientific Symposium „Poultry Days 2018“, 21-22. June 2018, Brno, Czech Republic, 30.

Muchacka, R., Sosnówka-Czajka, E., Skomorucha, I., Kapusta, E., Greń, A., Goc, Z. (2016). Lipid peroxidation, antioxidant enzymes activity and glutathione level in eggs from heritage breed and commercial crosses hens. Proceedings of $12^{\text {th }}$ International Scientific Conference "Animal Physiology 2016", May $13^{\text {th }}-15^{\text {th }} 2016$, Borretice, Czech Republic, 191-196.

Ohkawa, H., Ohishi, N., Yagi, K. (1979). Assay for lipid peroxides in animal tissues by thiobarbituric acid reaction. Analytical Biochemistry, 95, 351-358.

Singh, R., Cheng, K.M., Silversides, F.G. (2009). Production performance and egg quality of four strains of laying hens kept in conventional cages and floor pens. Poultry Science, 88(2), 256-264. DOI: $10.3382 /$ ps.2008-00237

Surai, P. (2015). Antioxidant systems in poultry biology: superoxide dismutase. Journal of Animal Research and Nutrition, 1(1), 1-8. DOI: 10.21767/2572-5459.100008

\section{Abstract}

The objective of the study was to determine the activity of antioxidant enzymes and the level of GSH and MDA in the yolk and albumen of hen's eggs. The experiment was carried out with 99 hens of three heritage breeds ('Greenleg Partridge' - group I, 'Sussex' - group II, 'Rhode Island Red' - group III). Layers were reared in the litter system and had outdoor access. Birds were fed ad libitum standard diets based on concentrates for laying hens and had free access to water throughout the experiment. All the groups were managed under uniform environmental (air humidity and temperature, lighting programme) and feeding conditions. At 48 weeks of age, 6 eggs from each group were collected. In the samples of egg yolks and albumens, the concentration of GSH and MDA, and activity of SOD, GPx, and CAT were estimated. The results were statistically analysed by one-way analysis of variance, and significant differences were estimated with Duncan's multiple range tests. The highest activity of SOD, the highest level of GSH, and the lowest level of MDA were 
characterised by eggs from 'Sussex' hens, which may indicate that they have the best quality. Based on the obtained results, it can be concluded that the activity of antioxidant enzymes (mainly SOD) and the levels of GSH and MDA that occur in eggs may depend on the breed of hens.

Key words: antioxidant enzymes, eggs, GSH, hens, MDA

Received: [2018.05.15]

Accepted: [2018.07.30]

\section{Aktywność enzymów antyoksydacyjnych, poziom GSH i MDA w jajach pochodzących od kur ras zachowawczych}

Streszczenie

Celem doświadczenia było zbadanie aktywności enzymów antyoksydacyjnych oraz poziomu GSH I MDA w żółtkach i białkach jaj kurzych. Materiał doświadczalny stanowiło 99 kur trzech ras zachowawczych ('Zielononóżka Kuropatwiana' - I grupa, 'Sussex' - II grupa i 'Rhode Island Red' - III grupa). Nioski utrzymywano w systemie ściółkowym z możliwością korzystania z trawiastych wybiegów. Ptaki karmiono ad libitum standardową paszą przygotowaną na bazie koncentratów dla kur niosek. W trakcie doświadczenia nioski miały swobodny dostęp do wody. Wszystkie grupy były utrzymywane w jednakowych warunkach środowiskowych (wilgotność powietrza i temperatura, program świetlny) i żywieniowych. W 48. tygodniu życia, z każdej grupy zebrano po 6 jaj. W próbkach żółtek i białek oznaczono poziom GSH i MDA oraz zbadano aktywność SOD, GPx i CAT. Wyniki zostały opracowane statystycznie za pomocą jednoczynnikowej analizy wariancji, szacując istotności różnic testem Duncana. Najwyższą aktywnością SOD, najwyższym poziomem GSH i najniższym poziomem MDA charakteryzowały się jaja od kur rasy 'Sussex', co może wskazywać na ich najlepszą jakość. Na podstawie uzyskanych wyników można stwierdzić, iż aktywność enzymów antyoksydacyjnych (głównie SOD) oraz poziom GSH i MDA występujących w jajach mogą zależeć od rasy kur.

Słowa kluczowe: enzymy antyoksydacyjne, jaja, GSH, kury, MDA

\section{Information on the authors}

Renata Muchacka https://orcid.org/0000-0002-8255-006X

She is an assistant professor at the Department of Animal Physiology and Toxicology in the Institute of Biology, Pedagogical University of Cracow. She is interested mainly in animal physiology, oxidative stress in animals, and the quality of food products of animal origin.

Ewa Sosnówka-Czajka https://orcid.org/0000-0003-3720-1685

She is an assistant professor at the Department of Poultry Breeding in the National Research Institute of Animal Production in Cracow. She is interested mainly in poultry welfare and the technology of poultry production.

Iwona Skomorucha https://orcid.org/0000-0003-1241-7703

She is an assistant professor at the Department of Poultry Breeding in the National Research Institute of Animal Production in Cracow. She also focuses on poultry welfare and the technology of poultry production.

Edyta Kapusta https://orcid.org/0000-0002-4350-5514

She is a laboratory specialist at the Department of Animal Physiology and Toxicology in the Institute of Biology, Pedagogical University of Cracow. She is interested in animal physiology, mainly in oxidative stress in animals.

Agnieszka Greń https://orcid.org/0000-0003-2383-1096

She is a professor at the Department of Animal Physiology and Toxicology in the Institute of Biology, Pedagogical University of Cracow. She is interested mainly in animal physiology, diabetes, and natural products, predominantly in diabetes prevention and therapy. 
Zofia Goc https://orcid.org/0000-0001-9626-5895

She is an assistant professor at the Department of Animal Physiology and Toxicology in the Institute of Biology, Pedagogical University of Cracow. She is interested in research on animal cells in vitro and animal physiology. 